\title{
Development of Self-Propelled Direct Seeded Rice Planter
}

\author{
R.A. Bangale $^{1 *}$, I. Srinivas ${ }^{2}$ and A.K. Dave ${ }^{1}$ \\ ${ }^{1}$ Department of Farm Machinery and Power Engineering, SVCAET, IGKV, Raipur, \\ Chhattisgarh, India \\ ${ }^{2}$ CRIDA, Hyderabad, India \\ *Corresponding author
}

\section{A B S T R A C T}

The agricultural operational holding in India is about 1.15 ha and 85.01 per cent belongs to marginal holdings (below 2 ha). This data shows an economic condition of the Indian

\section{Keywords}

Self-propelled, Rice, Planter, Direct seeded, Zero tillage.)

\section{Article Info}

Accepted:

10 February 2019

Available Online:

10 March 2019 farmer, which doesn't allow him to adopt advanced agricultural machineries. Considering the situation of Indian farmer, we developed a prototype of self-propelled direct seeded rice planter. This machine helps to plant a dry rice seed along with the fertilizer application with zero tillage condition. The machine includes inclined plate metering mechanism for seed; cup feed metering mechanism for fertilizer, seed cum fertilizer hopper, ground wheel, depth control wheels, inverted $\mathrm{T}$ furrow openers, $5 \mathrm{hp}$ engine as a prime mover, power transmission system, adjustable handle, lever and rigid main frame to support all the parts and drive wheels. The machine consists of two parts viz., prime mover part and planter cum fertilizer applicator part and both can be separated from each other. The machine places the rice seed up to average depth of $25-40 \mathrm{~mm}$ and spacing between hills is observed to be $130-160 \mathrm{~mm}$ along with an average $20 \mathrm{~cm}$ of row spacing. The average field capacity at an average speed of $2.3 \mathrm{~km} \cdot \mathrm{h}^{-1}$ is observed to be $0.115 \mathrm{ha} \cdot \mathrm{h}^{-1}$ for planting rice seeds. The field efficiency is observed to be 86.9 per cent. The operational cost is observed to be around 69.28 per cent less than the manual planting of rice seedling and also the man hour's requirement is very less than the manual planting.

\section{Introduction}

Rice (Oryza sativa L.) is a principal source of food for more than half of the world population. In India, Rice is grown on an area of about $43.5 \mathrm{~m}$ ha with a total production of 1091.49 lakh MT during 2016-17 and a productivity of $2.4 \mathrm{~T} \mathrm{ha}^{-1}$ during 2014-15 (Anonymous, 2017).Chhattisgarh has 38.16 lakh ha land under rice cultivation with rice production of about 57.89 lakh tonnes and with the productivity of $1517 \mathrm{~kg} \mathrm{ha}^{-1}$ during the year 2015-16 (Anonymous, 2016).

Transplanting has been one of the major traditional methods of rice establishment in which repeated puddling is done. Puddling benefits rice by reducing water percolation losses, controlling weeds, facilitating easy seedling establishment and creating anaerobic conditions to enhance nutrient availability (Sanchez et al., 1973). But, repeated puddling 
affects soil physical properties by destroying soil aggregates, reducing permeability in subsurface layers and forming hard-pans at shallow depths (Aggarwal et al., 1995; Sharma et al., 1985; Sharma et al., 2003). Manual Transplanting typically needs about 20 man-days $\mathrm{ha}^{-1}$, whereas direct wet seeding requires about 1-2 man-days $\mathrm{ha}^{-1}$.Direct seeded rice (DSR), probably the oldest method of crop establishment, is gaining popularity because of its low-input demand (Kaur and Singh, 2017; Farooq et al., 2009; Joshi et al., 2013). It offers certain advantages viz., saves labour, less water requirement, less drudgery, early crop maturity, low production cost, better soil physical conditions for following crops and less methane emission. Hence, it provides better option to be the best fit in different cropping systems (Farooq et al., 2009).

For direct seeding of pre germinated rice seeds, drum seeders are developed by many researchers with different designs in India. Drum seeders are either pulled by man or by animal in puddled field condition which involves drudgeries and is classified as a heavy work (Mathankar et al., 2006). There are tractor drawn inclined plate planters and seed drills available for direct seeding of rice but the cost as well as availability of the tractor during sowing season is a big problem for a small farmers. According to Agricultural Census 2010-11, the average size of operational holding in India is 1.15 ha. There are85.01 per cent land holdings are marginal holdings (below 2.00 ha), 14.29 per cent semi-medium and 3.7 per cent large holdings.

This data shows that the owner's economical condition does not allow him/her to use advanced agricultural machinery which helps him to improve the quantity as well as quality of the work as it is too expensive for him to be afforded. So, by considering the fact that most of the Indian farmers belong to marginal land holding, there is a need to develop the agricultural machinery which is small, inexpensive as well as viable. Therefore, it was proposed to develop a self-propelled zero till direct seeded rice planter cum fertilizer applicator.

\section{Materials and Methods}

A self-propelled direct seeded rice planter (Fig. 1) is developed in the Faculty of Agricultural Engineering, IGKV, Raipur, Chhattisgarh, collaborating with CRIDA, Hyderabad. The major components are main frame, hopper, metering unit (seed and fertilizer), furrow opener, seed tubes, ground wheel, depth control wheels, power source, speed reduction unit, power transmission, drive wheels and handle. The specifications for the planter are mentioned in table 1.

\section{Machine components}

\section{Main frame}

Two types of main frames are developed viz., Planter main frame and Prime mover main frame. The planter main frame of the prototype is fabricated using $40 \mathrm{~mm}$ square of thickness $3 \mathrm{~mm}$. Seed and fertilizer hopper, metering mechanism and furrow openers are mounted on the planter main frame. The depth control wheels are attached with the planter main frame at rear side and to the left side, ground wheel attachment is mounted.

The Prime mover main frame is fabricated by using $75 \mathrm{~mm}$ angles of thickness $5 \mathrm{~mm}$ on which engine, gear box (speed reduction unit) and handle are mounted. Two drive wheels, at both ends of the shaft are fixed at the front side using bearings below the prime mover main frame. The handle is mounted at rear side of prime mover main frame for easy turning of the machine. 


\section{Hopper}

The prototype is provided with trapezoidal hopper with three compartments for seed and three compartments for fertilizer of volumetric capacity $7123.74 \mathrm{~cm}^{3}$ and 6910.38 $\mathrm{cm}^{3}$ each respectively. The hopper is made up of $2 \mathrm{~mm}$ thick mild steel sheet. The design of hopper is made by considering required volumetric efficiency, bulk density and angle of repose for proper operation. The slope of the hopper wall is maintained as per the requirement of metering mechanism, which should be more than the angle of repose of rice seed.

\section{Metering unit}

An Inclined plate metering mechanism is developed for seed metering with notched disc which is suitable for rice to maintain particular plant to plant spacing. The seed plate is mounted on a set of bevel gears at an angle of 50 degree, which helps to maintain exact amount of seed in notch up to the outlet. The poly vinyl chloride material is used to develop circular metering plates of diameter $120 \mathrm{~mm}$ and thickness $6 \mathrm{~mm}$. Circular plates have 7 slanted circular notches on periphery. The notch is designed as per the physical properties of rice seed. Different small, medium and large seed varieties have been used to design a perfect slanted circular notch for rice. The seed dropping height from ground level is maintained to $500 \mathrm{~mm}$.

\section{Furrow opener and seed tubes}

Inverted T type furrow openers of $190 \mathrm{~mm}$ length each, are provided along with the seed outlet and $285 \mathrm{~mm}$ shank height is maintained. Furrow openers are attached with the main frame with the help of rigid $U$ clamps. Inverted $T$ type furrow opener makes a slight cut into the soil with reduced soil disturbance and seed placed in it. Seeds are covered by the loose soil during operation hence, covering device is not provided for this system. The transparent plastic pipes of 25 $\mathrm{mm}$ diameter with $2 \mathrm{~mm}$ thickness are used as seed tubes.

\section{Ground wheel}

Ground wheel is the driver of the metering mechanism for the planter, which provides power to rotate the metering plate and deliver a seed at an outlet. The MS flat of $30 \mathrm{~mm}$ with $5 \mathrm{~mm}$ thickness is used to make a ground wheel of diameter $265 \mathrm{~mm}$. It is provided with 12 pegs (Kumar et al., 2014) made of MS $30 \times 5 \mathrm{~mm}$ plate with $80 \mathrm{~mm}$ height and 6 spokes made of iron rod of size $10 \mathrm{~mm}$ are provided. Ground wheel to metering plate speed ratio is maintained to $2.25: 1$ to get proper seed to seed distance.

\section{Depth control wheels}

Two depth control wheels are provided at the rear side of the main frame. MS flat of $50 \mathrm{X}$ $10 \mathrm{~mm}$ is used to fabricate $200 \mathrm{~mm}$ diameter depth control wheels. During operation these wheels control the depth of sowing, while during transport these acts as support wheels to the machine. The nut bolt adjustment is provided to adjust the height of these wheels.

\section{Power source}

A 163 cc, 4-stroke, overhead valve, single cylinder, inclined type of $25^{\circ}$, horizontal shaft, $3600 \mathrm{rpm}, 3.6 \mathrm{~kW}$, recoil start, petrol run engine with 3.1 liter fuel tank is used to drive the planter. As a planter is driven by the engine, it becomes a self-propelled unit. Maximum net torque $10.3 \mathrm{Nm}$ is available at $2500 \mathrm{rpm}$.

\section{Speed reduction unit}

A gear box with speed reduction unit of 49:1 is used. The power of engine is transferred to 
speed reduction unit with the help of belt and pulley mechanism. The input and output shafts are parallel to each other and perpendicular to the direction of travel. With this speed reduction unit, $3600 \mathrm{rpm}$ is reduced to $75 \mathrm{rpm}$. The total weight of engine and gear box is $24 \mathrm{~kg}$.

\section{Drive Wheels}

Two types of drive wheels are provided with this prototype. first type of drive wheels are of hard rubber tires for transportation purpose, while second types of drive wheels are provided for working in the different filed conditions. The wheels provided for the field use are traction wheels of diameter $300 \mathrm{~mm}$ with lugs and pegs made of MS steel flat.

\section{Power transmission}

The power from engine is provided to the drive wheel with the help of gear box for forward motion to the planter. While for seed metering mechanism, the power is provided from the ground wheel through chain and sprocket mechanism and pairs of bevel gears. The speed ratio between ground wheel and metering plate is maintained to $2.25: 1$.

\section{Handle}

Based on the anthropometric data of Chhattisgarh farmers, the handle is designed with height of 62 to $93 \mathrm{~cm}$ (Verma et al., 2004). The height of handle is adjustable for better operation and more human comfort. The grip diameter and grip length recommended for handle uses in Chhattisgarh is 25 to $37.5 \mathrm{~mm}$ and 12.5 to $15 \mathrm{~cm}$ respectively (Verma et al., 2004). Hence, mild steel pipe of diameter $32 \mathrm{~mm}$ is used to fabricate the handle and the grip length is kept to $15 \mathrm{~cm}$. The clutch cables and acceleration cables are attached with handle for proper operation of machine.

\section{Performance evaluation}

The prototype is evaluated at laboratory as well as in field for its performance with rice seeds. The prototype is evaluated at the average speed of $2.3 \mathrm{~km} \mathrm{~h}^{-1}$. The calibration of seed planter is done at laboratory condition for seed rate and plant spacing as per IS: 6316-1993. The row to row spacing and plant to plant spacing for rice seeds is maintained as $20 \mathrm{~cm}$ and $15 \mathrm{~cm}$ respectively. The field evaluation of self-propelled rice planter cum fertilizer applicator was conducted in the experimental farm of IGKV, Raipur, Chhattisgarh. Performance of the prototype is indicated by the plant to plant distance, field capacity, field efficiency and fuel consumption.

\section{Field capacity}

Theoretical field capacity is the rate of field coverage that would be achieved if the planter is operated continuously without interruption like turning at the ends and filling of hopper. It is given as

Theoretical field capacity (ha $\mathrm{h}^{-1}$ ) = mean working width $(\mathrm{cm}) \mathrm{X}$ mean spead $(\mathrm{m}$ per s)X 36 10000

Effective field capacity is the actual average rate of field coverage including the time lost in filling and turning at the ends of rows [13]. It is given as

Effective field capacity (ha $\left.\mathrm{h}^{-1}\right)=$ total area cultivated (ha)

total work time (h)

\section{Field efficiency}

It is given as

$\begin{aligned} & \text { Field efficiency } \\ & \text { effective field capacity }\end{aligned}$
theoretical field capacity




\section{Results and Discussion}

The performance data of the Self-propelled direct seeded rice planter is presented in table 2. The average field capacity of the machine is found to be $0.115 \mathrm{ha}^{-1} \mathrm{~h}^{-1}$ at average speed of $2.3 \mathrm{~km} \cdot \mathrm{h}^{-1}$ for planting of rice seed. The field efficiency is observed to be 82.6 per cent for rice seed. Similar results were reported by Behera et al., (1995). Field tests indicated that the man-hour requirement of rice planter is 8.69 per hectare. The average seed placement depth is recorded as $25 \mathrm{~mm}$ to $40 \mathrm{~mm}$ for rice seeds against the recommended depths of 20 $\mathrm{mm}$ to $30 \mathrm{~mm}$. The spacing between hills and rows were observed to be of an average 130 $\mathrm{mm}$ to $160 \mathrm{~mm}$ and average $180 \mathrm{~mm}-200 \mathrm{~mm}$ respectively, against the recommended spacing of $150 \mathrm{~mm}$ and $200 \mathrm{~mm}$ respectively. The average germination percentage recorded in field is 73.68 per cent. No breakdown, repairs and adjustments during operation was needed. As the machine is laterally balanced with equal distribution of weight throughout the prototype, it can be handled easily by the operator. All these performance indices indicate that the developed prototype worked satisfactorily at field condition.

Table.1 Specifications

\begin{tabular}{|l|l|l|}
\hline & Component & Specification \\
\hline $\mathbf{1}$ & Overall size & 1210 X 1055 X $681 \mathrm{~mm}$ \\
\hline $\mathbf{2}$ & Net weight & $110 \mathrm{~kg}$ \\
\hline $\mathbf{3}$ & Number of rows & 3 (adjustable to two or 3) \\
\hline $\mathbf{4}$ & Row spacing & $20 \mathrm{~cm}$ (adjustable up to $25 \mathrm{~cm}$ for 3rows) \\
\hline $\mathbf{5}$ & Hill spacing & $15 \mathrm{~cm}$ (adjustable by changing metering plate) \\
\hline $\mathbf{6}$ & Seed metering & Inclined plate metering mechanism \\
\hline $\mathbf{7}$ & Fertilizer metering & Cup feed metering mechanism \\
\hline $\mathbf{8}$ & Seed hopper & $\begin{array}{l}\text { Trapezoidal cross section, 3 numbers with capacity } 7123.74 \\
\mathrm{~cm}^{3} \text { each. }\end{array}$ \\
\hline $\mathbf{9}$ & Fertilizer hopper & $\begin{array}{l}\text { Trapezoidal cross section, 3 numbers with capacity } 6910.38 \\
\mathrm{~cm}\end{array}$ \\
\hline $\mathbf{1 0}$ & Furrow opener \\
\hline $\mathbf{1 1}$ & Power source & Inverted T type, 3 nos. \\
\hline $\mathbf{1 2}$ & Power transmission & 5 Hp petrol engine \\
\hline $\mathbf{1 3}$ & Gearbox speed reduction ratio & Chain and sprockets, belt and pulley, bevel gears \\
\hline $\mathbf{1 4}$ & $\begin{array}{l}\text { Speed ratio (ground wheel to } \\
\text { metering plate }\end{array}$ & $2.25: 1$ \\
\hline
\end{tabular}

Table.2 Field performance parameter

\begin{tabular}{|l|l|l|}
\hline & Field performance parameter & Value \\
\hline $\mathbf{1}$ & Depth of placement $(\mathrm{mm})$ & 25 to 40 \\
\hline $\mathbf{2}$ & Spacing between hills $(\mathrm{mm})$ & 130 to 160 \\
\hline $\mathbf{3}$ & Number of seeds per hill (No) & 2 to 3 \\
\hline $\mathbf{4}$ & Forward speed $\left(\mathrm{km} \mathrm{h}^{-1}\right)$ & 2.3 \\
\hline $\mathbf{5}$ & Fuel consumption $\left(\mathrm{h}^{-1}\right)$ & 0.7 \\
\hline $\mathbf{6}$ & Field capacity $\left(\mathrm{ha} \mathrm{h}^{-1}\right)$ & 0.115 \\
\hline $\mathbf{7}$ & Field efficiency $($ per cent) & 82.6 \\
\hline
\end{tabular}


Fig.1 Self-propelled zero till direct seeded rice planter cum fertilizer applicator

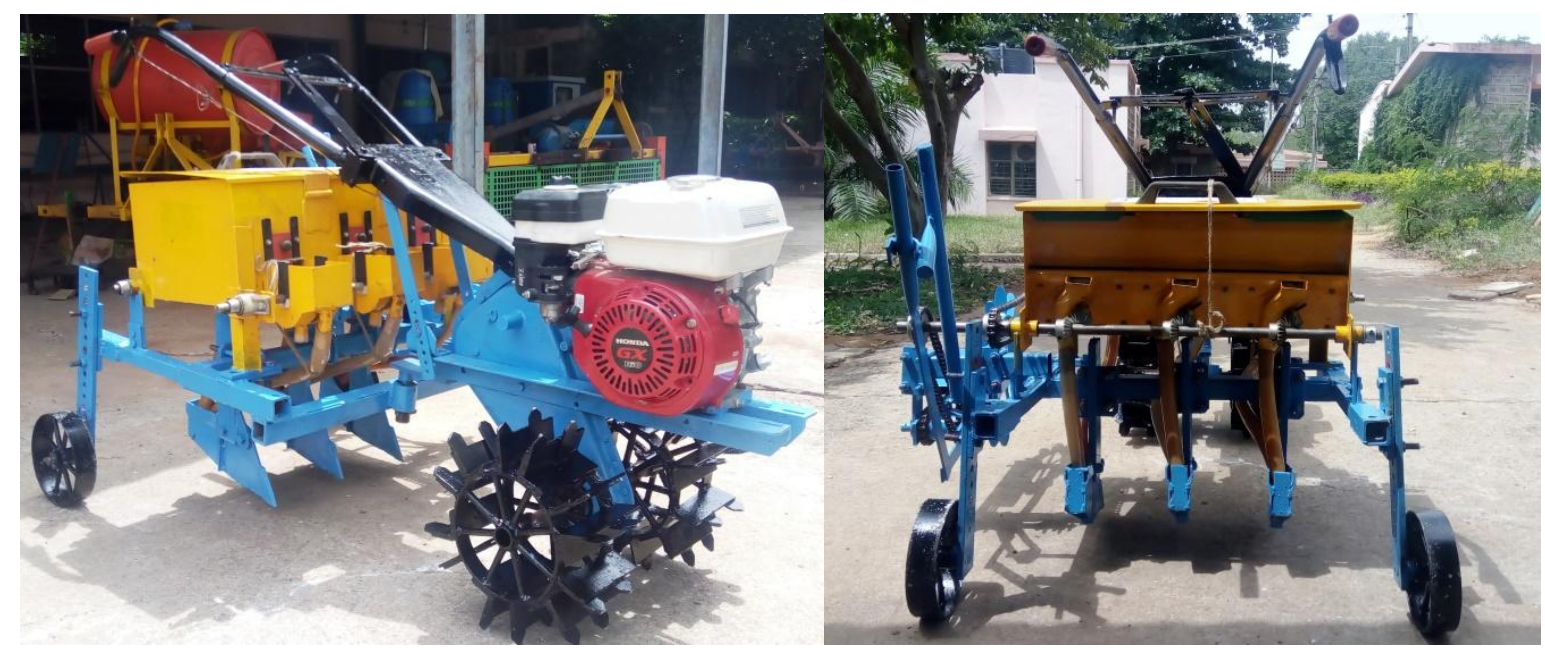

In conclusion, the average field capacity of the prototype is $0.115 \mathrm{ha} \mathrm{h}^{-1}$ at average speed of $2.3 \mathrm{~km} \mathrm{~h}^{-1}$. 2-3 seeds dropped per hill at the hill spacing of $130 \mathrm{~mm}$ to $160 \mathrm{~mm}$ at a depth of $25 \mathrm{~mm}$ to $40 \mathrm{~mm}$. Fuel consumed during the field operation is recorded as $0.71 \mathrm{~h}^{-1}$. The field efficiency was 82.6 per cent for rice planting with fertilizer application. Man hour requirement for this machine is less than the manual planting of rice. The machine is found to be suitable for small farmers having land holding below 2 hectare.

\section{Acknowledgement}

The author would like to gratefully acknowledge the DST-INSPIRE for financial assistance and Central Research Institute of Dry land Agriculture, Hyderabad and Indira Gandhi Krishi Vishwavidyalaya, Raipur for providing infrastructural facilities for this project.

\section{References}

Aggarwal, G. C., Sidhu, A. S., Sekhon, N. K., Sandhu, K. S., and Sur, H. S. (1995). Puddling and

$\mathrm{N}$ management effects on crop response in a rice-wheat cropping system. Soil
Tillage Research 36, 129-139.

Anonymous (2017).Area and production of rice in India. http// www.indiastat.com

Anonymous (2016).Area and production of rice in India. http// www.indiastat.com

Behera, B. K., P. K. Sahoo, S. Swain and D. Behera (1995). Evaluation of seeding devices for

dry land paddy. Agricultural mechanization in Asia, Africa and Latin America, vol.26 No.4, 17-21.

Farooq, M., Wahid, A., Lee, D.-J., Ito, O., Siddique, K.H.M., (2009).Advances in drought resistance of rice. Crit. Rev. Plant Sci. 28, 199-217.

Joshi Ekata, Dinesh Kumar, B. Lal, V. Nepalia, Priyanka Gautam and A. K. Vyas (2013). Management of Direct seeded rice for enhanced resource use efficiency. Plant Knowledge Journal, 2(3):119-134.

Kaur Jagmohan and Avtar Singh (2017). Direct seeded rice: prospectus, problems/ constraint and researchable issues in India. Current agriculture research Journal. Vol. 5(1), 1332(2017).

Kumar S., Mishra B P, Patel S K and Dave A. K. (2014). Design and development of power tiller operated seed cum ferti 
drill machine. African Journal of Agricultural Research, 9(51): 37763781.

Mathankar S. K., K. P. Saha, S. K. Rautaray and V. V. Singh (2006). Development and evaluation of self-propelled rice ridge seeder for pre germinated seeding. I. Agriculture Engineering Jouranl, 15(2-3): 79-89.

Sanchez, P. A. (1973). Puddling tropical soils. 2. Effects on water losses. Soil Sci. $115,303-308$.

Sharma, P. K., and De Datta, S. K. (1985).Effect of puddling on soil physical properties and processes. In "Soil Physics and Rice", pp. 217234.International Rice Research
Institute, Los Banos, Philippines.

Sharma, P. K., Ladha, J. K., and Bhushan, L. (2003). Soil physical effects of puddling in rice-wheat cropping systems. In "Improving the Productivity and Sustainability of Rice-Wheat Systems: Issues and Impacts" (J. K. Ladha, J. E. Hill, J. M. Duxbury, R. K. Gupta, and R. J. Buresh, Eds.), pp. 97-113. ASA, CSSA, SSSA, Madison, WI, ASA Special Publication 65.

Verma A. K., 2004. Design and development of seed cum fertilizer drill for mechanical and ergonomics consideration. http://hdl.handle.net/ $10603 / 84464$.

\section{How to cite this article:}

Bangale, R.A., I. Srinivas and Dave, A.K. 2019. Development of Self-Propelled Direct Seeded Rice Planter. Int.J.Curr.Microbiol.App.Sci. 8(03): 987-993.

doi: https://doi.org/10.20546/ijcmas.2019.803.119 